\title{
Oncogenic viruses: DUBbing their way to cancer
}

Nehul Saxena and Vijay Kumar*

*Correspondence: vijay@icgeb.res.in

Virology Group, International centre for genetic engineering and biotechnology, Aruna Asaf Ali Marg, New Delhi-110067, India.

\begin{abstract}
Ubiquitination is one of the most important post-translational modifications of proteins with a profound effect on their intracellular stability and activity. Deubiquitinases (DUBs), on the other hand, act by removing the ubiquitin moiety from proteins and thereby reverse their stability and/or activity. Besides, DUBs play a major role in maintenance of free ubiquitin pool, histone modification, vesicular trafficking and receptor recycling. The revelation of DUB interactome by Sowa et al., [1] highlighted the importance of DUBs in key cellular pathways. While the role of E3 ubiquitin ligases in the virus biology is well documented, the involvement of DUBs in viral life cycle is still being probed. Recent findings suggest DUBs could play a central role in invasion and pathogenesis of oncogenic viruses. Viral oncoproteins such as E6 and E7 of human papilloma virus and Tax of human T-cell leukemia virus type 1 are now known to target cellular DUBs such as cyclindromatosis tumor suppressor, ubiquitin-specific proteases 7, 11, 15 and 20, A-20 and signal-transducing adaptor molecule binding protein-like-1 in order to improve their intracellular stability and/or subjugate cellular signaling pathways. The viral oncoprotein-DUB interactions create an ambience leading to unbridled proliferation of virus-infected cells and drive cell transformation. Interestingly, some viruses like herpes simplex virus-1, Epstein-Barr virus, human cytomegalovirus and Kaposi's Sarcoma-associated herpes virus also encode their own DUBs such as UL36, UL48, BPLF1 and ORF64 to support viral invasion, replication, and persistence and even subvert host immune responses. Efforts are also underway to find specific inhibitors that can abrogate the interaction between cellular DUB and viral oncoproteins or inhibit viral DUBs as this might result in the development of next generation cancer chemotherapeutic agents. This review showcases the relevance of the viral DUBs and the cellular DUBs with interacting viral partners in virus-triggered cancer development.
\end{abstract}

Keywords: Deubiquitinase, interactome, oncogenic viruses, ubiquitination, ubiquitin proteasome system

\section{Introduction}

Ubiquitin is a highly conserved 76-amino acid polypeptide that is encoded by at least four different genes in mammalian cells, viz., UBA52, UBB, UBC and RPS27a. While the UBB and UBC genes code for poly-ubiquitin precursors, UBA52 and RPS27A genes encode fusion proteins $L 40$ and S27a, respectively. These precursor proteins are processed by the cellular endopeptidases to release identical mono-ubiquitins [2].

Ubiquitination is a process of conjugation of a monoubiquitin moiety or polyubiquitin moieties to lysine residues in a target molecule [3,4]. Ubiquitination of proteins could affect their stability, intracellular localization, conformation and activity, protein-protein interaction and even chromatin modification [5]. Thus, ubiquitination has profound effect on different cellular processes including protein turnover, transcription, cell cycle progression, signal transduction pathways, host defense, endocytosis, receptor recycling, chromatin remodeling, apoptosis, angiogenesis, DNA repair, nuclear export of mRNA, phospholipid balance, etc $[3,5,6]$.

The process of ubiquitination is dependent on the action of three main enzymes - E1 universal ubiquitin activating enzyme, E2 ubiquitin conjugating enzyme and E3 ubiquitin ligase [3,4]. The E4 ubiquitin ligase often acts in association with E3 ubiquitin ligase to increase E3 Ligases processivity or to facilitate ubiquitin chain extension on mono-ubiquitinylated substrates [7]. Ubiquitination involves nucleating monoubiquitin moiety or polyubiquitin chains on single or multiple lysine residues of substrate such as Lys 6 , Lys 11, Lys 27, Lys 29, Lys 33, Lys-48 and Lys 63. Of these, ubiquitination at Lysine 11 (K$11)$, Lysine $48(\mathrm{~K}-48)$ and lysine $63(\mathrm{~K}-63)$ are the most studied ubiquitination. While the ubiquitination at $\mathrm{K}-63$ usually regulates the intracellular localization and the activity of substrates, polyubiquitination at K-11 and K-48 are invariably involved in the degradation of target proteins [8].

The process of ubiquitination can be subverted by an inventory of proteases called deubiquitinases or DUBs that can either cleave the isopeptide bond between the $\varepsilon$-amino group of lysine side chains or a-amino acid of substrates and the C-terminal group of ubiquitin [9]. These proteases play a key role: a) in maintenance of free ubiquitin pool, b) histone modification, c) protein stability or activity, d) vesicular trafficking, and e) receptor recycling. Further, by effecting the proteins stability or activity, DUBs can also modulate the cell signaling pathways, cell cycle progression, DNA damage repair pathways, immune responses and apoptosis (Figure 1) [10]. Apart from their normal cellular functions, mutations or altered expression levels of DUBs and the perturbation caused by DUBs in a repertoire of pathways and physiological processes (viz., Chromatin remodeling, signaling pathways, immune response, cell cycle progression, angiogenesis, apoptosis and stress response) 


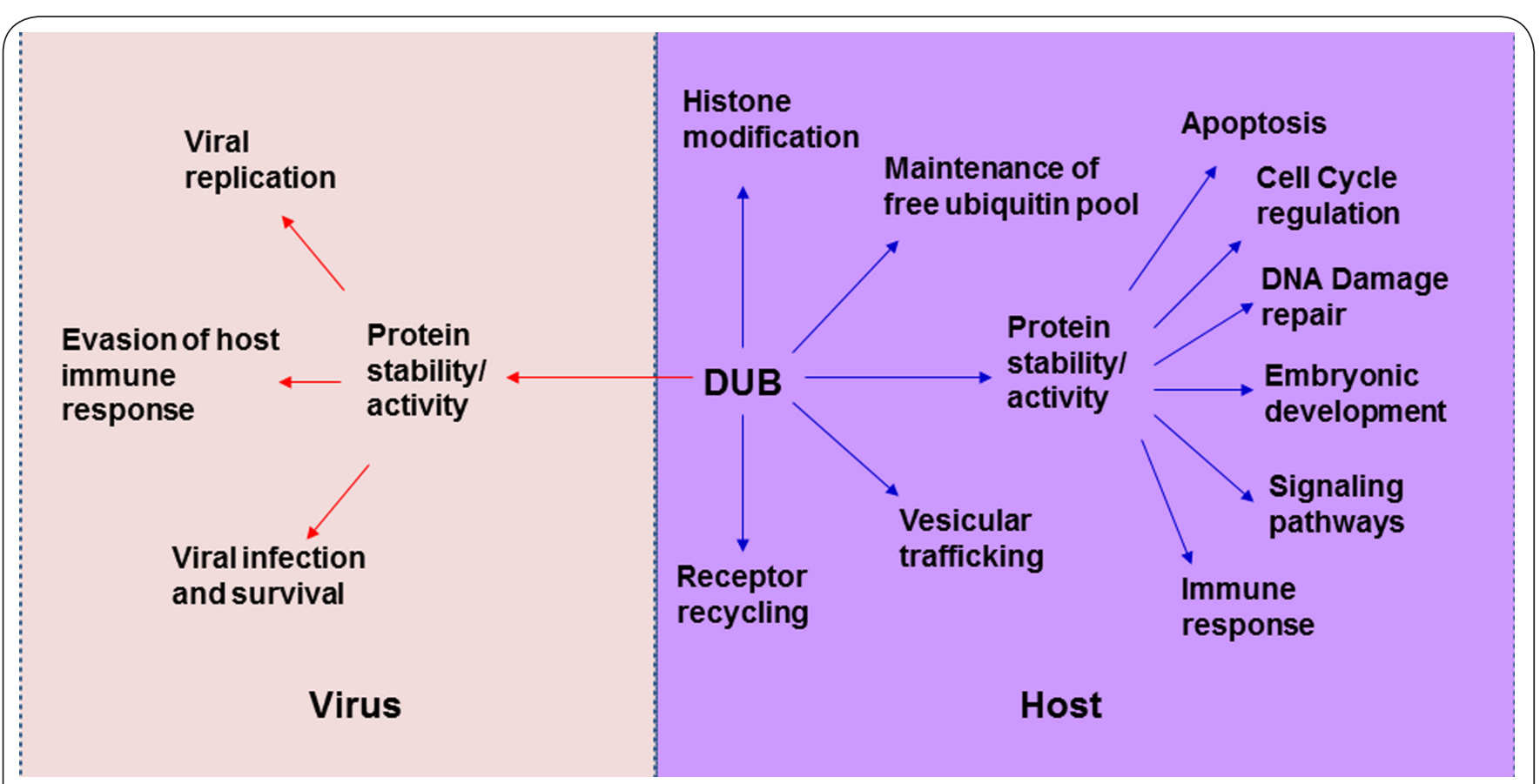

Figure 1. Pleiotropic DUBs-Multiple roles of DUBs in Viral and Host systems.

underlie the development of numerous cancers and disorders with predisposition to various cancers in humans (Table 2). Of late, DUBs are reported to play a central role in the life cycle of many human pathogens including some oncogenic viruses. These viruses not only engage cellular DUBs but also encode their own DUBs to support virus invasion, replication, and persistence or to subvert host immune responses [11].

The human genome encodes for atleast 98 known DUBs which have been classified into 6 different families (Table 1)(i) ubiquitin-specific proteases (USPs), (ii) ubiquitin carboxyterminal hydrolases (UCHs), (iii) ovarian-tumor proteases (OTUs), (iv) Machado-Joseph disease protein domain proteases (MJD), (v) Jab1/Mov34/Mpr1 (JAMM) metalloprotease deubiquitinase and (vi) monocyte chemotactic protein-induced protein (MCPIP) family. Most of the DUBs are typical cysteine proteases (USPs, UCH and Josephin family of proteases) with a few exceptions that are metalloproteases viz., JAMMs and anomalous cysteine proteases, viz., OTUs and MCPIP [9,12-14].

USP's form the largest and the most diverse family of DUBs characterized by ubiquitin specific protease domain; domain in ubiquitin specific protease (DUSP); ubiquitin interaction Motifs (UIMs); ubiquitin associated domains (UAD); B-box; Zn finger domain and Exonuclease III domain. Some vegetative homologues lack the catalytically active cysteine and histidine boxes, yet retain the ubiquitin binding activity. The tumor suppressor cylindramatosis (CYLD) and C19-papain family of proteases are the bona-fide members of USPs. Many USPs are reported to play a role in carcinogenesis $[9,12,14]$.

UCHs were the first structurally characterized DUBs with a ubiquitin carboxy-terminal hydrolases domain. They include four known members in humans- UCHL1, UCHL3, UCHL5/ $\mathrm{UCH} 37$ and BAP1. UCHs can efficiently process short ubiquitin chains due to a constricting loop in catalytic site of its members. They are actively involved in maintaining the intracellular ubiquitin pool. They are known to play a significant role in

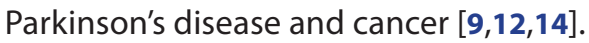

OTUs constitute a 15 member strong family of proteases in humans. Apart from the ovarian tumor domain, the members also have UIMs, UAD and $\mathrm{Zn}$ fingers. The members are divided into 3 sub-classes- Otubains, A20 like OTUs and OTUDs. Unlike typical cysteine proteases, they lack a complete catalytic triad. Some OTUs are regulated in tumorigenesis $[9,12,14]$.

The Josephin family of DUBs includes cysteine proteases with a single cysteine box, double histidine box and UIM domain. Four members of this family are encoded by humans. They have been implicated in diseases like spino-cerebellar ataxia, Machado-Joseph disease and cancer $[9,12,14]$.

The JAMM family of proteases is the most conserved family of DUBs. They are zinc-metalloproteases by nature. So far, just 12 members of JAMMs have been reported in humans. These are recruited for vesicle trafficking and receptor recycling. They have also been implicated in some cancers $[\mathbf{9 , 1 2 , 1 4 ]}$.

The MCPIP family of DUBs are unique cysteine protease which lack histidine box inside the $\mathrm{N}$-terminal catalytic triad. These are characterized by the presence of a UAD and a conserved $\mathrm{N}$-terminal domain, a $\mathrm{Zn}$-finger domain in the middle region and a $\mathrm{C}$-terminal proline-rich domain. With seven known members, these are reported to play a role in cancer related pathways $[9,12,13]$.

USP6 was the first DUB to be identified as an oncoprotein 
Saxena and Kumar Virology Discovery 2013,

Table 1. DUB's implicated in various cancers and cancer related pathways.

\begin{tabular}{|c|c|c|c|c|}
\hline \multicolumn{4}{|c|}{ A. Cancer associated DUBs (CAD)- DUBs with altered expression or inherent mutations in cancers } & References \\
\hline CYLD & \multicolumn{3}{|c|}{$\begin{array}{l}\text { Cylindromatosis, Brooke Spiegler Syndrome, Trichoepithelioma, hepatocellular carcinoma, colon cancer, kidney cancer, uterine } \\
\text { cervix carcinoma, and malignant melanoma }\end{array}$} & {$[12,14,40]$} \\
\hline USP1 & \multicolumn{3}{|c|}{ Fanconi Anemia and Gastric cancer } & {$[41]$} \\
\hline USP2 & \multicolumn{3}{|c|}{ Breast tumor, Glioma, oral squamous cell carcinoma, Ovarian Carcinoma and prostrate carcinomas } & {$[12,14,42,43]$} \\
\hline USP4 & \multicolumn{3}{|c|}{ Small-cell lung carcinoma } & {$[12]$} \\
\hline USP6 & \multicolumn{3}{|c|}{ Benign bone tumor and Neoplastic aneurismal bone cysts } & {$[12,44]$} \\
\hline USP7 & \multicolumn{3}{|c|}{ Multiple myeloma, prostrate cancer, non-small cell lung carcinomas, renal carcinoma and colon cancer } & {$[12,14,45]$} \\
\hline USP9X & \multicolumn{3}{|c|}{ Breast cancer, pancreatic-ductal adenocarcinoma, cervical carcinoma } & {$[46-48]$} \\
\hline USP10 & \multicolumn{3}{|c|}{ Breast cancer, glioblastoma multiforme, Multiple melanoma } & {$[12,48,49]$} \\
\hline USP11 & \multicolumn{3}{|c|}{ Malignant melanoma } & {$[41]$} \\
\hline USP14 & \multicolumn{3}{|c|}{ Cholangiocarcinoma } & {$[50]$} \\
\hline USP15 & \multicolumn{3}{|c|}{ Paclitaxel resistant ovarian cancer and Glioblastoma } & {$[12]$} \\
\hline USP17 & \multicolumn{3}{|c|}{ Primary lung, colon, esophagus and cervix tumor } & {$[12]$} \\
\hline USP20 & \multicolumn{3}{|c|}{ Von Hippel-Lindau cancer syndrome } & {$[12]$} \\
\hline USP22 & \multicolumn{3}{|c|}{$\begin{array}{l}\text { Papillary thyroid carcinoma,Non-small cell lung carcinoma, Oral squamous cell carcinoma, human esophageal } \\
\text { squamous cell carcinoma, Malignant melanoma and colorectal carcinomas, Gastric carcinoma, breast cancer }\end{array}$} & {$[12,49,51-56]$} \\
\hline USP25 & \multicolumn{3}{|c|}{ Breast Cancer } & {$[48]$} \\
\hline USP28 & \multicolumn{3}{|c|}{ Lobular breast carcinoma and colon cancer } & {$[12,14]$} \\
\hline USP32 & \multicolumn{3}{|c|}{ Breast Cancer } & {$[57]$} \\
\hline USP33 & \multicolumn{3}{|c|}{ Von Hippel-Lindau cancer syndrome andB cell-acute lymphoblastic leukemia } & {$[12,56,58]$} \\
\hline USP42 & \multicolumn{3}{|c|}{ Acute Myeloid leukemia } & [59] \\
\hline USP44 & \multicolumn{3}{|c|}{ Human T-cell leukemia } & {$[60]$} \\
\hline USP48 & \multicolumn{3}{|c|}{ Malignant melanoma } & {$[41]$} \\
\hline UCHL1 & \multicolumn{3}{|c|}{ Meningiomas, Protrate cancer, non-small cell lung carcinomas and Breast cancer } & {$[12,61,62]$} \\
\hline UCHL5 & \multicolumn{3}{|c|}{ Human esophageal squamous cell carcinoma } & {$[63]$} \\
\hline BAP1 & \multicolumn{3}{|c|}{ Breast cancer, pleural mesotheliomas, uveal melanomas, cutaneous melanoma and Non-small cell lung cancer } & {$[12,14,64]$} \\
\hline A20 & \multicolumn{3}{|c|}{$\begin{array}{l}\text { Lymphomas- including B cell lymphomas, Hodgkin lymphoma, mantle cell lymphoma, MALT lymphoma, marginal zone } \\
\text { lymphoma }\end{array}$} & {$[12,14]$} \\
\hline JOSD1 & Nonsmall & 11 lung carcinoma & & {$[41]$} \\
\hline CSN5 & Nonsmall c & 11 lung carcinomas, Nasopharyngeal Carcir & oma, malignant melanoma & {$[12,41]$} \\
\hline & & B. Cancer related redundant & athway associated DUBs (CRRPAD) & Reerences \\
\hline $\begin{array}{l}\text { Chroma } \\
\text { associate }\end{array}$ & in DUBs & $\begin{array}{l}\text { DUBs participating in Chromatin } \\
\text { remodelling }\end{array}$ & $\begin{array}{l}\text { USP3, USP7, USP10, USP11, USP16, USP21, USP22, BAP1, BRCC36, } \\
\text { MYSM1 and UCHL5 }\end{array}$ & {$[12,14,65]$} \\
\hline & & DNA Damage repair related DUBs & $\begin{array}{l}\text { USP1, USP3, USP7S, USP11, USP16, USP24, USP28, USP47, BRCC36, } \\
\text { OTUB1 and POH1 }\end{array}$ & {$[12,66-68]$} \\
\hline & & $\begin{array}{l}\text { Innate immune response and } \\
\text { Inflammatory pathways - JAK-STAT } \\
\text { pathway JNK-p38-MAPK pathway; TLR } \\
\text { pathway }\end{array}$ & USP2, USP4, USP11, USP15, USP17, USP18, USP25, A20 and MCPIP1 & [69-77] \\
\hline $\begin{array}{l}\text { DUBs } \\
\text { manipul }\end{array}$ & ating the & NFk $\beta$ Signalling pathway & $\begin{array}{l}\text { USP2, USP4, USP6, USP7, USP11, USP15, USP21, A20, CYLD, } \\
\text { MCPIP1, OTUD5, OTUD7B and Cezanne }\end{array}$ & {$[12,70,78-82]$} \\
\hline Signallin & g pathways & $\begin{array}{l}\text { p53- and Cyclin dependent kinase } \\
\text { Inhibitor (CKI) related pathways }\end{array}$ & $\begin{array}{l}\text { USP2, USP4, USP5, USP7, USP10, USP11, USP22, USP29, SP37, } \\
\text { UCHL1 and OTUB1 }\end{array}$ & {$[12,62,83-86]$} \\
\hline & & $\begin{array}{l}\text { PI3K-AKT related pathways-RTK } \\
\text { dependent pathways, MTOR pathway, } \\
\text { GSK3 } \beta \text { pathway }\end{array}$ & USP1, USP8, USP 9X, USP22 and UCHL1 & {$[84,87-90]$} \\
\hline & & TGF- $\beta$ pathway & USP4, USP9X, USP11, USP15, STAMBPL1and UCHL5 & {$[12,91]$} \\
\hline & & Wnt pathway & USP4, USP15, USP34, CYLD, UCHL1 and TRABID & {$[12,92]$} \\
\hline & & $\begin{array}{l}\text { ROR (Reactive oxygen species related) } \\
\text { pathway }\end{array}$ & USP1, USP7, USP10 and A20 & {$[93-96]$} \\
\hline DUBs al & tering the $\mathrm{C}$ & 1 Cycle progression & $\begin{array}{l}\text { USP2, USP3, USP7, USP13, USP17L2, USP19, USP28, USP37, USP39, } \\
\text { USP44, USP50, CSN5, BAP1, CYLD and OTUB-6B }\end{array}$ & {$[12,97]$} \\
\hline Angioge & nesis and $\mathrm{m}$ & astasis related DUBs & $\begin{array}{l}\text { USP2, USP2a, USP8, USP18, USP19, USP20, USP28, USP33, USP47, } \\
\text { Cezanne, ATXN3L, and MCPIP1 }\end{array}$ & [98-106] \\
\hline DUBs in & volved in $A_{l}$ & ptosis & $\begin{array}{l}\text { USP2, USP7, USP8, USP9X, USP15, USP16, USP17, USP18, USP19, } \\
\text { USP52, A20, ATXN3 CYLD, UCHL1 and MCPIP1 }\end{array}$ & {$[12,107,108]$} \\
\hline DUBs in & duced upon & ytokine secretion & USP17, USP17L2 and TUD-6B & {$[97]$} \\
\hline
\end{tabular}


Saxena and Kumar Virology Discovery 2013,

http://www.hoajonline.com/journals/pdf/2052-6202-1-5.pdf

doi: $10.7243 / 2052-6202-1-5$

Table 2. Classification and characteristics of DUBs.

\begin{tabular}{|c|c|c|c|c|}
\hline DUB Family & No. of members & Features & Examples & References \\
\hline $\begin{array}{l}\text { Ubiquitin specific } \\
\text { proteases (USPs) }\end{array}$ & $>50$ & $\begin{array}{l}\text { - Include three subdomains - finger, thumb and palm. Finger } \\
\text { domain interacts with ubiquitin. } \\
\text { Carry cysteine and histidine boxes embedded in a region } \\
\text { spanning approximately } 300 \text { to } 800 \text { a.a. with a regulatory aspartate } \\
\text { box } \\
\text { May have other extra domains namely, UIM, UAD, B-Box, DUSP, } \\
\text { Zn finger, ULD, Exonuclease III domains. } \\
\text { Interaction with ubiqutin triggers a conformational change } \\
\text { leading to their activation }\end{array}$ & $\begin{array}{l}\text { CYLD, C19 family of } \\
\text { papain protease }\end{array}$ & [9] \\
\hline $\begin{array}{l}\text { Ubiquitin C-terminal } \\
\text { hydrolase (UCH) }\end{array}$ & 4 & $\begin{array}{l}\text { - Can process only small peptides (20 to } 30 \mathrm{aa} \text { ) from the C-terminus } \\
\text { of ubiquitin. } \\
\text { - Involved in ubiquitin recycling by targeting inappropriately } \\
\text { conjugated ubiquitin on nucleophiles. } \\
\text { - Also generate monoubiquitins by processing polyubiquitin chains } \\
\text { and ubiquitin conjugated to ribosomal protein precursor. }\end{array}$ & $\begin{array}{l}\text { UCHL1, UCHL3, } \\
\text { UCHL5/UCH37 and } \\
\text { BAP1 }\end{array}$ & [9] \\
\hline $\begin{array}{l}\text { Ovarian Tumor } \\
\text { domain proteases } \\
\text { (OTUs) }\end{array}$ & $\begin{array}{l}\text { Include } \\
3 \text { sub- families } \\
\text { Otubains, A20 like } \\
\text { OTUs and } \\
\text { OTUDs }\end{array}$ & $\begin{array}{l}\text { - Have an active cysteine protease domain. The core domain has five } \\
\beta \text {-strands, situated between the helical domains. } \\
\text { The catalytic triad is incomplete and is stabilized by hydrogen } \\
\text { bonding complex. } \\
\text { - May carry auxiliary domains like-Zn finger domain, UIMs and } \\
\text { UAD. }\end{array}$ & $\begin{array}{l}\text { Otubains (OTUB1 } \\
\text { and OTUB2) } \\
\text { A20-like OTUs (A20/ } \\
\text { TNFAIP3; Cezanne, } \\
\text { Cezanne 2, TRABID } \\
\text { and VCPIP1) } \\
\text { OTUDs(OTUD1, } \\
\text { OTUD2/ } \\
\text { YOD1,OTUD3, } \\
\text { OTUD4, OTUD5, } \\
\text { OTUD6A, OTUD6B } \\
\text { and ALG13) }\end{array}$ & [9] \\
\hline $\begin{array}{l}\text { Josephin family of } \\
\text { DUBs }\end{array}$ & 4 & $\begin{array}{l}\text { - The family is named due to a pivotal role played by ATXN-3 in } \\
\text { spinocerebellar ataxia and Machado-Joseph disease. } \\
\text { In addition to the catalytic triad of one cysteine and two histidine } \\
\text { boxes, the members may have UIMs. } \\
\text { ATXN-3 has a polyubiquitin chain editing activity and ubiquitin } \\
\text { hydrolase activity while ATXN3L, JOSD1 and JOSD2 show DUB } \\
\text { activity. }\end{array}$ & $\begin{array}{l}\text { ATXN3, ATXN3L, } \\
\text { JOSD1 and JOSD2 }\end{array}$ & [9] \\
\hline JAMM proteases & 12 & $\begin{array}{l}\text { Are zinc-metalloproteases that target lys-63 linked polyubiquitin. } \\
\text { Also show isopeptidase activity for ubiquitin or ubiquitin like } \\
\text { proteins. } \\
\text { - Carry a well conserved JAMM domain (Jab1/Csn5 and MPN } \\
\text { domain). } \\
\text { - Involved in receptor recycling and vesicle trafficking. }\end{array}$ & $\begin{array}{l}\text { AMSH/STAMBP, } \\
\text { STAMBPL, BRCC36. } \\
\text { POH1/ PSMD14, } \\
\text { MYSM1, MPND and } \\
\text { CSN5/JAB1 }\end{array}$ & [9] \\
\hline MCPIP family & $\sim 7$ & $\begin{array}{l}\text { - Anomalous cysteine protease with only cysteine and aspartate } \\
\text { boxes within the conserved N-terminal catalytic region. } \\
\text { Carry an } \mathrm{N} \text {-terminal UAD, a conserved middle zinc-finger domain } \\
\text { and a proline-rich domain at its carboxy terminus. }\end{array}$ & MCPIP1 & [13] \\
\hline
\end{tabular}

[15]. Now it is well known that DUBs can function as both, an oncoprotein or a tumor suppressor and can also interact with a viral oncoprotein to drive oncogenesis $[12,14]$. Interestingly, viral DUBs have also been implicated as mediators of oncogenesis $[11,16]$. This review highlights the role of the interaction between viral oncoproteins and cellular DUBs (Table 3 ) and that of viral DUBs in virus mediated oncogenic transformations (Table 4).

\section{Review}

Rendezvous of cellular DUBs with viral oncoproteins Oncogenic viruses build a strong line of communication within the host cell to support their survival and propagation. Viral oncoproteins act as pawns for hijacking cellular machinery
(Figure 2). The examples of viral manipulation of cellular DUBs are elaborated below:

\section{Human papilloma Virus (HPV) and CYLD}

$\mathrm{HPV}$ is the causative agent of cervix, head and neck cancers. The E6 oncoprotein of HPV promotes nuclear factor-KB(NFKB) signaling by antagonizing the functions of the cellular DUB, CYLD. Stimulation of NFKB signaling leads to increased cellular proliferation and survival in most cancers. The NFKB signaling is negatively regulated by $\mathrm{I \kappa} \beta$ protein that inturn is regulated by the Ік $\beta$ kinase (ІКк) complex which is composed of IKK- $\gamma$ (the regulatory unit), IKk- $\alpha$ and IKK- $\beta$ (the catalytic units). CYLD deubiquitinates the K-63 ubiquitinated IKK- $\gamma$ and other up stream regulators of NFKB such as TNF receptor associated 
Table 3. Interaction between Cellular DUBs and viral oncoproteins.

\begin{tabular}{|c|c|c|c|c|}
\hline Cellular DUB & Virus & Viral protein & Function & References \\
\hline \multirow[t]{2}{*}{$\begin{array}{l}\text { Cylindroma-tosis } \\
\text { tumor suppressor } \\
\text { (CYLD) }\end{array}$} & $\begin{array}{l}\text { Human papiloma virus- } 16 / 18 \\
\text { (HPV) }\end{array}$ & E6 & 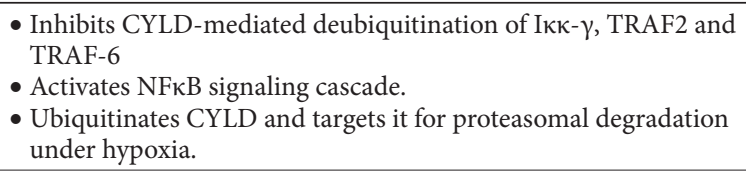 & {$[17]$} \\
\hline & $\begin{array}{l}\text { Human T-cell leukemia virus } \\
\text { type-1 (HTLV-1) }\end{array}$ & $\operatorname{Tax}$ & 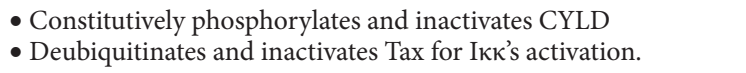 & {$[25]$} \\
\hline \multirow[t]{3}{*}{ USP 7/ HAUSP } & $\begin{array}{l}\text { Herpes simplex virus } \\
\text { type-1 (HSV-1) }\end{array}$ & ICP0 & 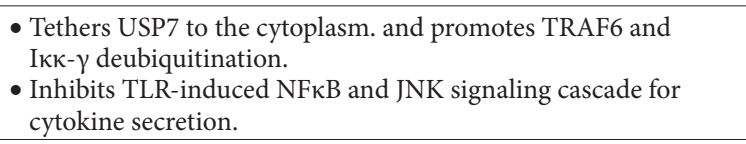 & {$[20]$} \\
\hline & Epstein Barr Virus (EBV) & EBNA1 & $\begin{array}{l}\text { - Recruits USP7 to the Ori P of episomal viral DNA. } \\
\text { USP7 in association with GMPS deubiquitinates the } \\
\text { monoubiquitinated H2B on the FR-controlled promoters and } \\
\text { stimulates transcription. }\end{array}$ & {$[21]$} \\
\hline & $\begin{array}{l}\text { Kaposi's sarcoma associated } \\
\text { Herpes virus (KSHV) }\end{array}$ & vIRF4 & $\begin{array}{l}\text { - Interferes with the p53-MDM-USP7 axis. } \\
\text { - Inhibits USP7 by acting as a pseudosubstrate and inhibiting } \\
\text { its catalytic activity. }\end{array}$ & {$[22]$} \\
\hline USP11 & HPV-16 & E7 & $\begin{array}{l}\text { - USP11 stabilizes and modulates the activity of E7 involved in } \\
\text { cell transformation. }\end{array}$ & {$[19]$} \\
\hline USP15 & HPV-16, HPV-18 & E6 & $\begin{array}{l}\text { - USP15 deubiquitinates and stabilizes E6 to promote cellular } \\
\text { transformation. }\end{array}$ & {$[18]$} \\
\hline USP20 & HTLV-1 & $\operatorname{Tax}$ & 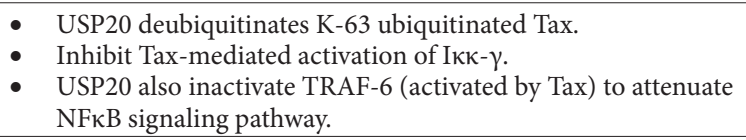 & {$[20]$} \\
\hline A20 & EBV & LMP1 & $\begin{array}{l}\text { - LMP1 stimulates A20 activity. } \\
\text { A20 inhibits the LMP1 triggered NFKB signaling pathway. } \\
\text { A20 also reverses the LMP1-mediated K-63 ubiquitination } \\
\text { and activation of IRF7. }\end{array}$ & {$[23]$} \\
\hline STAMBPL1 & HTLV-1 & $\operatorname{Tax}$ & 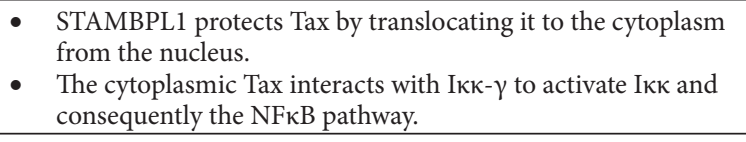 & {$[24]$} \\
\hline
\end{tabular}

Table 4. Viral DUBs and their functions.

\begin{tabular}{|c|c|c|c|c|}
\hline Viral DUB & Virus & DUB Activity & Function & References \\
\hline $\begin{array}{l}\text { UL48 capsid-associated } \\
\text { tegument protein }\end{array}$ & HCMV & $\begin{array}{l}\text { Ubiquitin-specific C-terminal } \\
\text { hydrolase (UCH) and Isopeptidase } \\
\text { activity for Lys - } 63 \text { residue }\end{array}$ & $\begin{array}{l}\text { Efficient viral growth at low MOI in cultured } \\
\text { cells. Specific mechanism is unknown. }\end{array}$ & {$[30]$} \\
\hline $\begin{array}{l}\text { ORF64- tegument } \\
\text { protein }\end{array}$ & KSHV & $\begin{array}{l}\text { Ubiquitin specific cysteine protease } \\
\text { (USP) which deubiquitinylates Lys- } 63\end{array}$ & $\begin{array}{l}\text { Deubiquitinates RIG-I to inhibit the host's anti-viral } \\
\text { IFN signaling cascade. }\end{array}$ & {$[38]$} \\
\hline $\begin{array}{l}\text { UL36 -inner tegument } \\
\text { protein }\end{array}$ & HSV-1 & USP with a lys- 48 preferential activity. & $\begin{array}{l}\text { Maintains the contact between capsid and tegument. } \\
\text { Role as a DUB is unknown. }\end{array}$ & {$[29]$} \\
\hline $\begin{array}{l}\text { BPLF1-viral tegument } \\
\text { protein }\end{array}$ & EBV & USP as well as DUB & $\begin{array}{l}\text { Deubiquitinates and inactivates the viral ribonucleo- } \\
\text { tide reductase subunit RR1. }\end{array}$ & {$[34]$} \\
\hline & -- & -- & $\begin{array}{l}\text { Inhibits host translesion synthesis by deubiquitinating } \\
\text { PCNA. }\end{array}$ & $\begin{array}{l}{[35]} \\
{[32]}\end{array}$ \\
\hline $\begin{array}{l}\text { BSLF1- component of } \\
\text { viral helicase-primase } \\
\text { complex }\end{array}$ & -- & DUB & Function as DUB unknown & {$[33]$} \\
\hline $\begin{array}{l}\text { BXLF1 - viral thymidine } \\
\text { kinase }\end{array}$ & -- & DUB & Function as DUB unknown & \\
\hline $\begin{array}{l}\text { EBNA3C- Latent viral } \\
\text { antigen }\end{array}$ & $\begin{array}{l}-- \\
--\end{array}$ & $\begin{array}{l}\text { DUB } \\
-- \\
--\end{array}$ & $\begin{array}{l}\text { Stabilizes itself to promote B-cell transformation. } \\
\text { Stabilizes Mdm } 2 \text { to promote p53 degradation. } \\
\text { Stabilizes Cyclin D1to promote pRb degradation. }\end{array}$ & $\begin{array}{c}{[36]} \\
-- \\
{[37]}\end{array}$ \\
\hline
\end{tabular}


Saxena and Kumar Virology Discovery 2013,

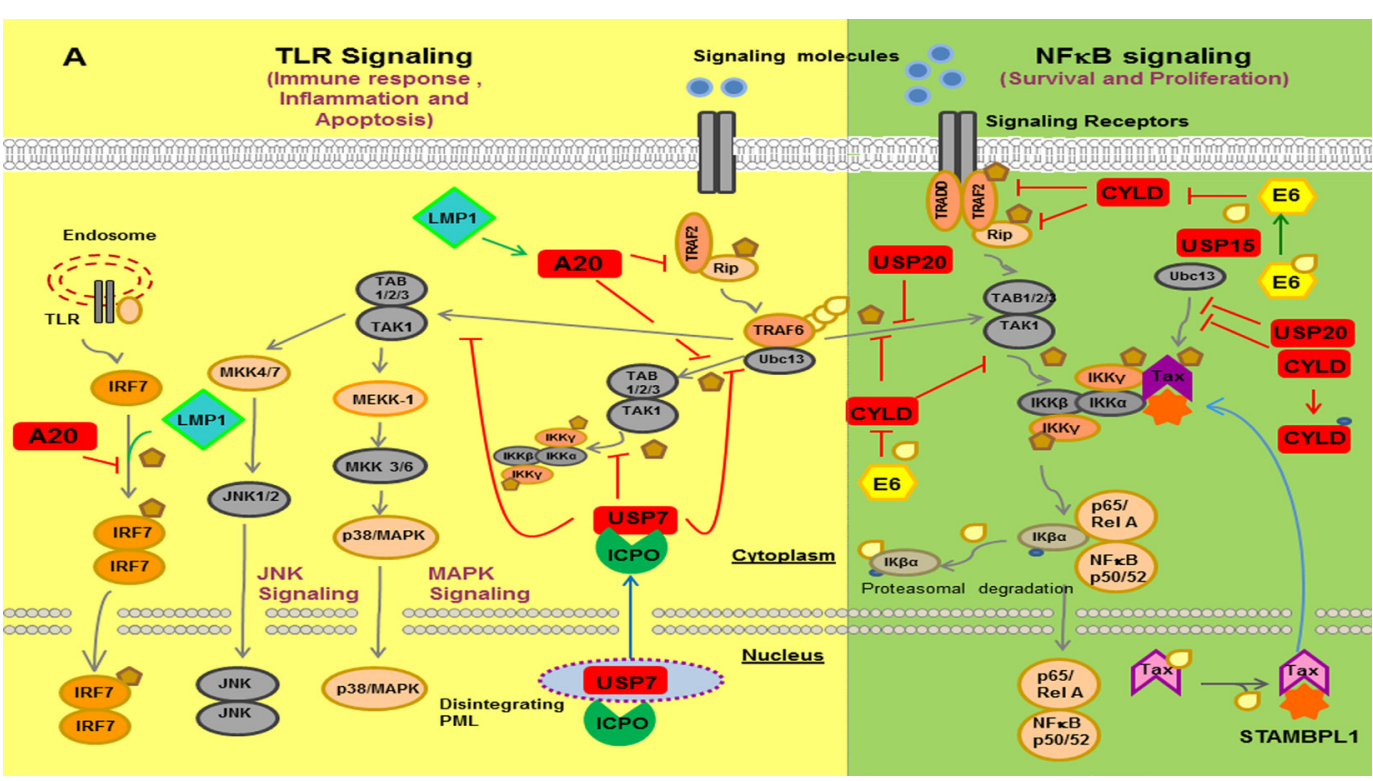

B

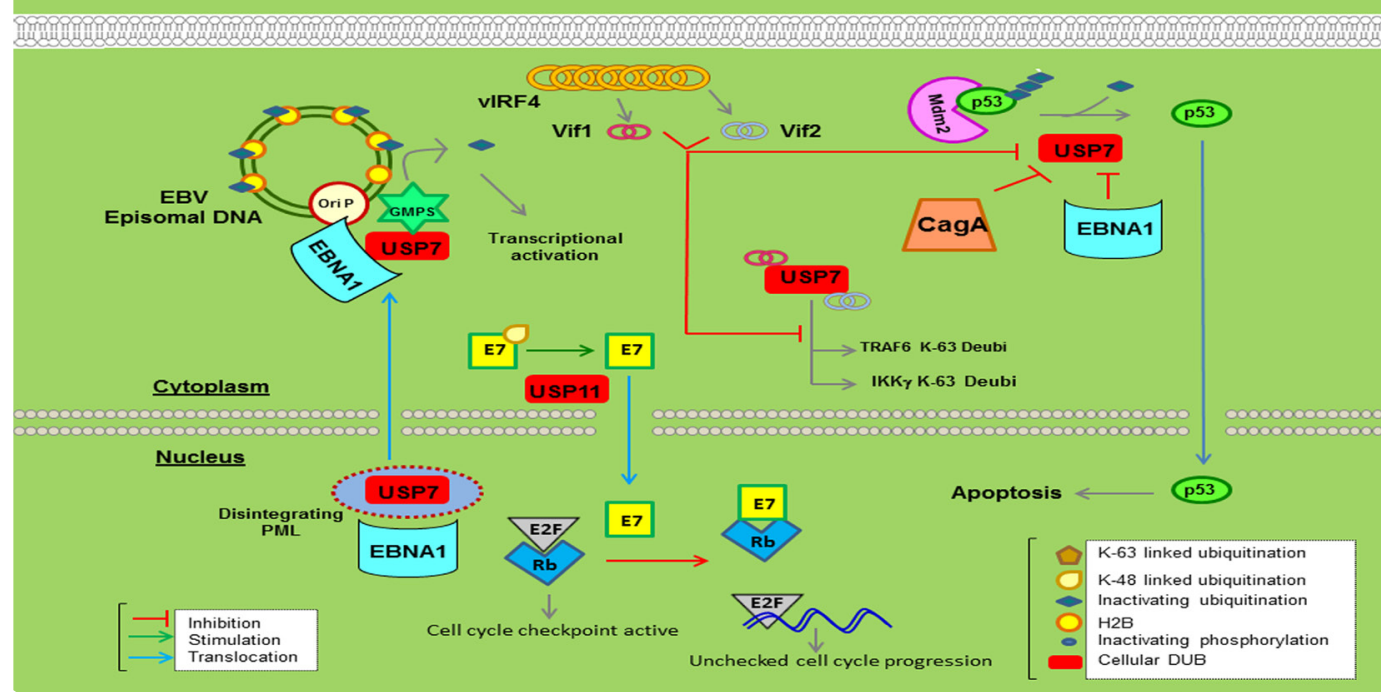

Figure 2. Cell signaling pathways and the regulatory networks of cellular DUBs and viral oncoproteins.

(A) (i) The E6 oncoprotein of HPV promotes NFאB signaling by promoting K-48 ubiquitination of cellular DUB- CYLD (a negative regulator of NFkB signaling- mediates TRAF-2, TRAF-6, Rip1 and Iкк- $\gamma$ via K-63 ubiquitination). Besides, E6 is also stabilized by USP15 to activate E6-mediated NFKB signaling. (ii) Tax protein of HTLV-1 is protected from K-48 ubiquitination and subsequent degradation by its translocation from nucleus to cytoplasm by STAMBPL1.The cytoplasmic Tax is kept in an active state by phosphorylation and inactivation of CYLD (as CYLD is responsible for deubiquitination of Tax at K-63 residue and its inactivation inside the HTLV-1 infected cells). Tax is able to activate the NFKB signaling pathway by promoting K-63 ubiquitination of Iкк- $\gamma$.Besides, HTLV-infected cells also suppress the levels of USP20 which prevents the inhibition of Tax activity and Tax-mediated activation of TRAF-6. (iii) ICP0 oncoprotein of HSV chaperones USP7 from cytoplasm to nucleus

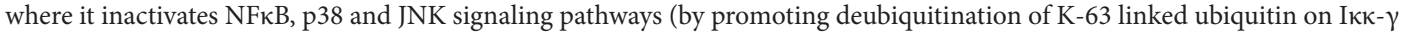
and TRAF-6) triggered by TLRs to immunoprotect the virus. (iv) The EBV transforming oncoprotein- LMP1, stimulates the expression of A20 cellular DUB to cause the inactivation of TLR-mediated signaling by promoting A20 interaction with TRAF-2. Activated A20 further prevents the LMP1mediated NFkB signaling by promoting K-48 ubiquitination of TRAF- 6 and Rip1. A20 also prevents LMP1 mediated K-63 ubiquitination and activation of interferon regulatory factor IRF7. (B) (i) The EBNA1 oncoprotein of EBV translocates USP7 to the cytoplasm in order to recruit it to the viral episomal DNA at OriP along with guanosine 5' monophosphate synthetase (GMPS). This causes deubiquitination of monoubiquitinylated H2B and its transcriptional activation. (ii) The peptides vif1 and vif2 derived from the vIRF4 of KSHV act as pseudosubstrate and catalytic inhibitor of USP7 to interfere with the K48 ubiquitination of Mdm2 and the subsequent activation of p53. vIRF4 can also abrogate the inactivation of NFkB signaling by USP7. CagA, the oncoprotein of Helicobacter pylori also targets USP7. 
oncoprotein exhibits increased interaction with CYLD and stimulates CYLD's ubiquitination and proteasomal degradation. Thus, the E6 oncoprotein tinkers with CYLD to create an ambience that may lead to cellular transformation [17].

\section{HPV and USP 15}

The E6 oncoprotein of HPV is also known to interact with USP15 to stabilize itself within the host cell. USP15 deubiquitinates E6 and enhances its intracellular stability. A high level of E6 ensures unfettered proliferation and transformation of the host cells [18].

\section{HPV and USP11}

The E7 oncoprotein of HPV is known to transform host cells by interfering with the $\mathrm{Rb}-\mathrm{E} 2 \mathrm{~F}$ axis through some undefined mechanisms. The HPV-infected cells program cellular DUBUSP11 to deubiquitinate $\mathrm{E} 7$ and protect it from proteasomal degradation. This increases the interaction of $\mathrm{E} 7$ with $\mathrm{pRb}$ and increases transforming potential of E7 by compromising $\mathrm{pRb}$ tumor suppressor activity. Thus, USP11 indirectly contributes toward smalignancy in host cells by conferring intracellular stability to the E7 viral oncoprotein [19].

\section{Herpes Simplex Virus (HSV) and USP7}

Infection of the immuno-suppressed patients by HSV is responsible for development of oral or genital tumors. Upon infection, HSV triggers the cytokine innate immune response via Toll-like receptors (TLRs) which entail NFkB and MAPK signaling. The immediate early viral protein, infected cell protein 0 (ICPO), circumvents the signaling events by engaging a deubiquitinating enzyme, USP7 also known as herpesvirus-associated ubiquitin-specific protease (HAUSP). ICP0 interacts with USP7 present inside the promyelocytic leukemia bodies (PML) within the nuclear compartment and tethers it to the cytoplasm. In cytoplasm, USP7 interacts with TRAF6 and IKK- $\gamma$ and removes their K-63 ubiquitin residues. The deubiquitination curbs the release of NFKB from the IKBa inhibitory complex and suppresses the cytokine secretion. Thus, HSV evades the host cytokine tsunami by engaging USP7 [20].

\section{Epstein Barr Virus (EBV) and USP7}

The EBV infected host cells in various phases of latency or after transformation are vulnerable to a plethora of malignancies like the Burkitt's lymphoma, Hodgkin's lymphoma, nasopharyngeal lymphoma, etc. Binding of the Epstein Barr nuclear antigen 1 or EBNA1 oncoprotein to the family of repeats (FR) on 'Ori P' drives the replication of episomal viral DNA in the latently infected cells. EBNA1 disrupts the PML congregations inside the nucleus, interacts with USP7 and sequester it to Ori P in the cytoplasm. At Ori P, USP7 deubiquitinates the monoubiquitinated $\mathrm{H} 2 \mathrm{~B}$ leading to the transcriptional activation of FR-controlled LMP1 and Cp promoter sessential for the virus life cycle. In parallel, EBNA1 binding to the $\mathrm{N}$-terminal TRAF-like domain of USP7 also jeopardizes the stability of p53 leading to unbridled proliferation of EBV infected cells [21].

\section{Kaposi's Sarcoma-Associated Herpes Virus (KSHV) and USP7}

Persistent infection of the immuno-compromised host with $\mathrm{KSHV}$ is associated with the development of Kaposi's sarcoma, primary effusion lymphoma and certain types of multi centric Castleman's disease. The yeast-two hybrid analysis has revealed that the viral interferon regulatory factor 4 (vIRF4) of KSHV physically interacts with USP7 to inhibit its functioning. The inhibitory functions of vIRF4 (912 amino acids in length) are attributed to two peptidesregions, Vif1 and Vif2 of vIRF4. Both Vif1 (residue 202-216) and Vif2 (residue 220-236) can bind to USP37 and curb its function as a p53 deubiquitinase. Thus, upon viral infection, vIRF4 is able to interfere with p53-HAUSPMdm2 axis to overcome the cell cycle pause and apoptosis induced by $\mathrm{p} 53$. These events promote uncontrolled cell proliferation and eventual transformation of host cells [22].

\section{EBV and A20 deubiquitinase}

The latent membrane protein-1 (LMP1) of EBV acts like an oncoprotein as it can transform both B and non B-cells. LMP1 induces the expression as well as activity of A20 - a dual E3 ubiquitin ligase and deubiquitinase, to inhibit TLR signaling and activation of. Briefly, this is achieved when the N-terminal OTU domain of A20 (with DUB activity) cleaves the K-63 linked ubiquitin from TRAF6 and receptor interacting protein 1 (Rip1). The C-terminal Zn finger domain of A20 subsequently catalyzes K-48 linked ubiquitination of TRAF6 and Rip1 leading to their proteasomal degradation. LMP1 also engages A20 which exercises its control over LMP1 at two levels. Firstly, A20 interacts TRAF2 to inhibit the LMP1 mediated NFkB and JNK signaling. Secondly, A20 counteracts the LMP1-mediated ubiquitination and activation of interferon regulatory factor 7 (IRF7). Thus, LMP1 effectively stimulates A20 to annihilate the inflammatory response of host cell [23].

\section{Human T-cell leukemia virus type 1 (HTLV-1) and STAMBPL1}

HTLV-1 is a viral carcinogen responsible for adult T-cell leukaemia (ATL). The Tax oncoproteinof HTLV-1 is known to activate the host NFKB pathway and engage the host transcriptional machinery to drive viral gene expression. Tax is known to shuttle across nuclear-cytoplasmic compartments of a cell to ensure its multiple functions. The K-63 ubiquitinated Tax (by UbC13) interacts with IKKү to permanently activate the IкK complex. Signal-transducing adaptor molecule binding protein-like 1 (STAMBPL1) is a DUB from the JAMM metalloprotease deubiquitinase family which acts as an accomplice to Tax. STAMBPL1 usually acts on the K-63 linked ubiquitin and plays a role in cell surface receptor recycling. In case of ATL, STAMBPL1 cooperates with Tax and promote its translocation from nucleus to the cytoplasm. This shuttling protects Tax from its K-48 linked ubiquitination and proteasomal degradation inside the nucleus. Thus, STAMBPL1mediated protection of Tax and its subsequent movement to 
Saxena and Kumar Virology Discovery 2013,

http://www.hoajonline.com/journals/pdf/2052-6202-1-5.pdf

doi: $10.7243 / 2052-6202-1-5$

the cytoplasm is responsible for the activation of I $\mathrm{kK}$ and NFKB by Tax and potentiation of T-cell transformation by HTLV-1 [24].

\section{HTLV-1 and CYLD}

The catalytically active CYLD is capable of deubiquitinating Tax oncoprotein at K-63 in the nucleus. This deubiquitinated Tax protein is incapable of activating lkk but not Tak1 (an activator of Ікк- $\beta$ ). As a result, IKBa-a NFKB inhibitor, is stabilized. To circumvent these events, the HTLV-1 transformed T-cells constitutively phosphorylate CYLD to make it catalytically compromised. Thus, the virus overcomes the CYLD-mediated $\mathrm{NFKB}$ in activation which is conducive for the proliferation of virus infected host cell [25].

\section{HTLV-1 and USP20}

The cellular USP20 is also capable of subverting the activity of Tax oncoprotein of HTLV. USP20 can either deubiquitinate TRAF- 6 and inactivate it or can deubiquitinate the K-63 polyubiquitinated Tax to prevent its association with IKK- $\gamma$ for its activation. Since such undesirable activity of USP20 can be detrimental for the NFKB signaling stimulated propagation of HTLV infected cells, its expression is automatically suppressed. This strategy favors unchecked proliferation and eventual transformation of the HTLV-infected cells [26].

\section{Viral DUBs}

Many viral proteins are being dubbed for havingdeubiquitinating activity. Such DUBs play key roles in the viral infection, survival and persistence. Of late, the human adenovirus, bunyavirus, coronavirus and herpesvirus have been reported to encode viral DUBs [27]. Examples of viral DUBs from oncogenic viruses are given in Table 4.

\section{Herpes simplex virus-1 (HSV-1) and UL36 ${ }^{\text {USP }}$}

The cleavage product UL $36^{\text {USP }}$ of the HSV-1 tegument protein UL36 (3266 amino acids), formed during the late stage of viral replication, act as a ubiquitin-specific cysteine protease [28] UL36 belongs to a unique class of viral DUB which bears no similarity to the eukaryotic DUBs. UL36 has a K-48 biased DUB activity. UL36 ${ }^{\text {USP }}$ DUB activity is confined to the $\mathrm{N}$-terminal500 amino acids. The relevance of the DUB activity of UL36 in viral life cycle remains to be unraveled [29].

\section{Human cytomegalovirus (HCMV) UL48 protein}

The viral DUB UL48 (253 kDa) of HCMV was discovered as a homolog of UL36 of HSV-1. UL48 has a ubiquitin C-terminal hydrolase/isopeptidase dual activity and is capable of cleaving both K-48 and K-63 linked ubiquitin moiety albeit the K-63 linked ubiquitin is preferred. UL48 is a cysteine peptidase with a characteristic Cys-His-Asp catalytic triad. The HCMV mutants of cysteine or histidine in the catalytic triad are replication competent but severely compromised for viral infection at very low multiplicity of infection. Therefore, the DUB activity of UL48 may be crucial in establishing infection in the host [30].

\section{DUBs of EBV}

Multiple sequence alignment, pattern search for conserved catalytic domain,Hidden-Makov model and search for conserved cysteine and histidine boxes with functional validation have revealed the presence of at least three ubiquitin-specific proteases encoded by EBV, viz., BPLF1, BSLF1, and BXLF1 [31]. Of the three proteins, BSLF1 protein along with BBLF4 and BBLF2/3 forms a helicase-primase complex for the viral DNA replication during the lytic phase of replication [32]. Its role as a DUB is unclear. BXLF1, on the other hand, functions as a viral thymidine kinase and its role as a DUB needs investigation [33].

BPLF1 is 3,149 amino acids long tegument protein with its $\mathrm{N}$-terminus 205 residues carrying the deubiquitinase activity. The association of large (RR1) and small (RR2) subunits of viral ribonucleotide reductase (RR) is essential for an active holoenzyme. During the late stage of infection, the $\mathrm{N}$-terminal 246 amino acids of BPLF1 associate with RR2 to juxtapose and deubiquitinate RR1 leading to the inactivation of viral RR. Thus, virus utilizes BPLF1 to switch off the RR activity dispensable during the later stages, which is otherwise essential for dNTP synthesis during the early phase of infection [34].

Unlike RR2 (viral partner of BPLF1), the proliferating cell nuclear antigen (PCNA) is an important host interacting partner of BPLF1. PCNA is an active participant in the post replication repair pathway in host cells. Lesions in DNA cause stalling of replication forks. The damaged DNA can still replicate by translesion synthesis or avoid doing so by template switching. During translesion synthesis, the host replication protein A coats single stranded damaged DNA and recruits Rad18. Rad18, in turn, monoubiquitinates PCNA at K-164 to augment its interaction with polymerase $\eta$ for translesion synthesis. The interaction between BPLF1 and PCNA leads to deubiquitination of PCNA to prevent its participation in translesion synthesis. Interestingly, BPLF1 not only disengages PCNA and derails the post-replication repair in the host but also engages free PCNA at viral episomal DNA to promote its own replication [35].

EBV nuclear antigen 3C (EBNA3C) which is responsible for $B$-cell transformation in the latent stage of EBV infection, also acts like a viral DUB. The N-terminal domain of EBNA3C encompasses the consensus cysteine box motif which works with the C-terminal consensus histidine box to carry out the DUB activity. The N-terminal domain of EBNA3C binds to the central acidic domain of $\mathrm{Mdm} 2$ inside the nucleus to stabilize Mdm2. EBNA3C also augments the E3 ligase activity of $\mathrm{Mdm} 2$ and brings p53 in close proximity to form a ternary complex to mediate p53 degradation [36]. EBNA3C via its $\mathrm{N}$-terminal domain also binds to $\mathrm{pRb}$ and Cyclin D1. Through its association with Cyclin D1, EBNA3C promotes the nuclear localization of Cyclin D1 which prevents former's phosphorylation by GSK3 $\beta$. As a result there is a decrease in the polyubiquitination and degradation of Cyclin D1. The resultant enhancement of the Cyclin D1/cdk6 kinase activity 
promotes the degradation of tumor-suppressor $\mathrm{pRb}$ and unchecked progression of cell cycle from G1 to $S$ phase. This leads to accumulation of genomic aberrations which causes cellular transformation [37].

\section{ORF64 of KSHV}

KSHV uses many viral genes to overcome the host innate immune response triggered via TLRs. The tegument protein ORF64 of KSHV is a viral cysteine protease with DUB activity that targets IFN signaling. KSHV replication is found to be especially sensitive to interferon alpha (IFNa). ORF 64 acts on retinoic acid inducible gene-I (RIG-I)- the pattern recognizing receptor in host cells, to attenuate IFN signaling. The(RIG-I) senses the viral nucleic acid and gets ubiquitinated onits $\mathrm{N}$-terminal CARD domain by TRIM 25 tripartite motif protein 25 (TRIM25). This leads to the activation of IFN cascade. ORF64 deubiqiutinates the K-63 ubiquitin present on the CARD domain of RIG-I and prevents RIG-I interaction with MAVS-CARD - its downstream signaling partner. These events lead to a down regulation of IFN- $\beta$ expression and enhanced viral resistance [38].

\section{Conclusion}

Ubiquitination is a reversible post-translational modification which might influence proteins stability, cellular localization and activity. Whereas, ubiquitination is mediated by E3 ubiquitin ligases, it can reversed by a family of protease known as deubiquitinases or DUBs. Close to 100 different DUBs are known in human cellsthat canbe divided into 6 sub families. Many viral proteins have also evolved to play DUB like roles. Though the viral DUBs exhibit cysteine protease activity, they appear to be unrelated to their eukaryotic counter parts. Many oncogenic viruses hijack the host deubiquitinase machinery or exploit their own DUBs to drive cellular transformation.

The relevance of viral and cellular DUBs in cancer biology is continuously being highlighted through various research efforts being made in this field. So far, seven cellular DUBs- CYLD, USP7, USP11, USP15, USP20, A20 and STAMBPL1 (AMSH-LP) out of $>100$ known DUBs have been associated with viral oncoproteins. Out of these, five DUBs, CYLD USP7, USP11, USP15 and USP20 belong to the USP family of cysteine protease; A20 belongs to the OTU family of cysteine proteases and STAMBPL1 belongs to the Zinc-metalloprotease family of DUBs.

Based on available literature, DUBs may be classified into two groups -(1) Cancer associated DUBs (CADs)-DUBs with altered expression or inherent mutation and (2) Cancer related redundant pathway associated DUBs (CRRPADs) (Table 2).

In stark contrast to the 52 DUBs implicated in cancer (an assimilation of all the CADs and CRRPADs) only 7 have been reported as interacting partners for viral oncoproteins. Thus, concerted efforts need to be made to overcome the lacunae in understanding the role of remaining cancer related DUBs in virus-induced carcinogenesis.

Since DUBs seem to play a significant role in cancer biology, many strategies are being adopted to manipulate them by chemotherapy (i.e., by using DUB inhibitors like ubiquitin aldehyde (Ubal), ubiquitin venylsulfone (UbVS), p5091, P022077,IUI1, etc.) [12,39]. Efforts are also under way to find inhibitors that can abrogate the interaction of cellular DUBs with viral oncoproteins. Considering the importance of neoviral DUBs in cellular transformation, an intensive search for specific inhibitors for viral DUBs is of paramount importance. Simultaneously, finding crucial roles for DUBs in cancer-related pathways would establish them as the next generation cancer chemotherapeutic target akin to the UPS which have been successfully targeted by drug Borteozomib.

\section{Competing interests}

The authors declare that they have no competing interests.

\section{Authors' contributions}

\begin{tabular}{|l|c|c|}
\hline Authors' contributions & NS & VK \\
\hline Research concept and design & -- & $\checkmark$ \\
\hline Collection and/or assembly of data & $\checkmark$ & -- \\
\hline Data analysis and interpretation & -- & $\checkmark$ \\
\hline Writing the article & $\checkmark$ & -- \\
\hline Critical revision of the article & -- & $\checkmark$ \\
\hline Final approval of article & -- & $\checkmark$ \\
\hline Statistical analysis & -- & -- \\
\hline
\end{tabular}

\section{Acknowledgement}

This work was supported by the Department of Biotechnology, Ministry of Science and Technology, Government of India, New Delhi (grant No. BT/PR12658/BRB/10/712/2009 to VK) and a senior research fellowship from the University Grants Commission, New Delhi (reference no. 20-6/2008(ii) EU-IV to NS).

\section{Publication history}

Editors: P. Daniel Ghiringhelli, National University of Quilmes, Argentina.

Qiyi Tang, Ponce School of Medicine, USA.

EIC: Preet M. Chaudhary, University of Southern California Keck School of Medicine, USA.

Received: 16-Sep-13 Revised: 09-Oct-13

Accepted: 10-Oct-2013 Published: 25-Oct-2013

\section{References}

1. Sowa ME, Bennett EJ, Gygi SP and Harper JW. Defining the human deubiquitinating enzyme interaction landscape. Cell. 2009; 138:389403. | Article | PubMed Abstract | PubMed Full Text

2. Catic $A$ and Ploegh HL. Ubiquitin--conserved protein or selfish gene? Trends Biochem Sci. 2005; 30:600-4. I Article I PubMed

3. lickman $\mathrm{MH}$ and Ciechanover $\mathrm{A}$. The ubiquitin-proteasome proteolytic pathway: destruction for the sake of construction. Physiol Rev. 2002; 82:373-428. | Article | PubMed

4. Pickart CM. Mechanisms underlying ubiquitination. Annu Rev Biochem. 2001; 70:503-33. | Article I PubMed

5. Schnell JD and Hicke L. Non-traditional functions of ubiquitin and ubiquitin-binding proteins. J Biol Chem. 2003; 278:35857-60. | Article | PubMed

6. Weissman $\mathrm{AM}$, Shabek $\mathrm{N}$ and Ciechanover $\mathrm{A}$. The predator becomes the prey: regulating the ubiquitin system by ubiquitylation and degradation. Nat Rev Mol Cell Biol. 2011; 12:605-20. | Article | 
Saxena and Kumar Virology Discovery 2013,

http://www.hoajonline.com/journals/pdf/2052-6202-1-5.pdf

doi: $10.7243 / 2052-6202-1-5$

\section{PubMed Abstract | PubMed Full Text}

7. Hoppe T. Multiubiquitylation by E4 enzymes: 'one size' doesn't fit all. Trends Biochem Sci. 2005; 30:183-7. | Article | PubMed

8. Kulathu $\mathrm{Y}$ and Komander D. Atypical ubiquitylation - the unexplored world of polyubiquitin beyond Lys48 and Lys63 linkages. Nat Rev Mol Cell Biol. 2012; 13:508-23. | Article I PubMed

9. Reyes-Turcu FE and Wilkinson KD. Polyubiquitin binding and disassembly by deubiquitinating enzymes. Chem Rev. 2009; 109:1495508. | Article | PubMed Abstract | PubMed Full Text

10. Komander D, Clague MJ and Urbe S. Breaking the chains: structure and function of the deubiquitinases. Nat Rev Mol Cell Biol. 2009; 10:55063. | Article | PubMed

11. Isaacson MK and Ploegh HL. Ubiquitination, ubiquitin-like modifiers, and deubiquitination in viral infection. Cell Host Microbe. 2009; 5:55970. | Article | PubMed

12. Fraile JM, Quesada V, Rodriguez D, Freije JM and Lopez-Otin C. Deubiquitinases in cancer: new functions and therapeutic options. Oncogene. 2012; 31:2373-88. | Article | PubMed

13. Liang J, Saad Y, Lei T, Wang J, Qi D, Yang Q, Kolattukudy PE and Fu M MCP-induced protein 1 deubiquitinates TRAF proteins and negatively regulates JNK and NF-kappaB signaling. J Exp Med. 2010; 207:2959-73. | Article | PubMed Abstract | PubMed Full Text

14. Shi $D$ and Grossman SR. Ubiquitin becomes ubiquitous in cancer: emerging roles of ubiquitin ligases and deubiquitinases in tumorigenesis and as therapeutic targets. Cancer Biol Ther. 2010; 10:737-47. | Article | PubMed Abstract | PubMed Full Text

15. Oliveira AM and Chou MM. The TRE17/USP6 oncogene: a riddle wrapped in a mystery inside an enigma. Front Biosci (Schol Ed). 2012; 4:321-34. | Article | PubMed

16. Randow F and Lehner PJ. Viral avoidance and exploitation of the ubiquitin system. Nat Cell Biol. 2009; 11:527-34. | Article | PubMed

17. An J, Mo D, Liu H, Veena MS, Srivatsan ES, Massoumi R and Rettig MB. Inactivation of the CYLD deubiquitinase by HPV E6 mediates hypoxiainduced NF-kappaB activation. Cancer Cell. 2008; 14:394-407. | Article | PubMed Abstract | PubMed Full Text

18. Vos RM, Altreuter J, White EA and Howley PM. The ubiquitin-specific peptidase USP15 regulates human papillomavirus type $16 \mathrm{E} 6$ protein stability. J Virol. 2009; 83:8885-92. | Article | PubMed Abstract | PubMed Full Text

19. Lin $\mathrm{CH}$, Chang HS and Yu WC. USP11 stabilizes HPV-16E7 and further modulates the E7 biological activity. J Biol Chem. 2008; 283:15681-8. I Article | PubMed Abstract | PubMed Full Text

20. Daubeuf S, Singh D, Tan Y, Liu H, Federoff HJ, Bowers WJ and Tolba K. HSV ICPO recruits USP7 to modulate TLR-mediated innate response. Blood. 2009; 113:3264-75. | Article | PubMed Abstract | PubMed Full $\underline{\text { Text }}$

21. Sarkari F, Sanchez-Alcaraz T, Wang S, Holowaty MN, Sheng $Y$ and Frappier L. EBNA1-mediated recruitment of a histone H2B deubiquitylating complex to the Epstein-Barr virus latent origin of DNA replication. PLoS Pathog. 2009; 5:e1000624. | Article | PubMed Abstract I PubMed Full Text

22. Lee HR, Choi WC, Lee S, Hwang J, Hwang E, Guchhait K, Haas J, Toth Z, Jeon YH, Oh TK, Kim MH and Jung JU. Bilateral inhibition of HAUSP deubiquitinase by a viral interferon regulatory factor protein. Nat Struct Mol Biol. 2011; 18:1336-44. | Article | PubMed Abstract | PubMed Full Text

23. Ning $\mathrm{S}$ and Pagano JS. The $\mathbf{A} 20$ deubiquitinase activity negatively regulates LMP1 activation of IRF7. J Virol. 2010; 84:6130-8. | Article | PubMed Abstract | PubMed Full Text

24. Lavorgna A and Harhaj EW. An RNA interference screen identifies the Deubiquitinase STAMBPL1 as a critical regulator of human T-cell leukemia virus type 1 tax nuclear export and NF-kappaB activation J Virol. 2012; 86:3357-69. | Article | PubMed Abstract | PubMed Full Text

25. Wu X, Zhang M and Sun SC. Mutual regulation between deubiquitinase CYLD and retroviral oncoprotein Tax. Cell Biosci. 2011; 1:27. | Article | PubMed Abstract | PubMed Full Text

26. Yasunaga J, Lin FC, Lu X and Jeang KT. Ubiquitin-specific peptidase 20 targets TRAF6 and human T cell leukemia virus type 1 tax to negatively regulate NF-kappaB signaling. J Virol. 2011; 85:6212-9. | Article | PubMed Abstract | PubMed Full Text

27. Edelmann MJ and Kessler BM. Ubiquitin and ubiquitin-like specific proteases targeted by infectious pathogens: Emerging patterns and molecular principles. Biochim Biophys Acta. 2008; 1782:809-16. | Article | PubMed

28. Cardone G, Newcomb WW, Cheng N, Wingfield PT, Trus BL, Brown JC and Steven AC. The UL36 tegument protein of herpes simplex virus 1 has a composite binding site at the capsid vertices. J Virol. 2012; 86:4058-64. | Article | PubMed Abstract | PubMed Full Text

29. Kattenhorn LM, Korbel GA, Kessler BM, Spooner E and Ploegh HL. A deubiquitinating enzyme encoded by HSV-1 belongs to a family of cysteine proteases that is conserved across the family Herpesviridae. Mol Cell. 2005; 19:547-57. | Article I PubMed

30. Kim ET, Oh SE, Lee YO, Gibson W and Ahn JH. Cleavage specificity of the UL48 deubiquitinating protease activity of human cytomegalovirus and the growth of an active-site mutant virus in cultured cells. J Virol. 2009; 83:12046-56. | Article | PubMed Abstract | PubMed Full Text

31. Sompallae R, Gastaldello S, Hildebrand S, Zinin N, Hassink G, Lindsten $\mathrm{K}$, Haas J, Persson B and Masucci MG. Epstein-barr virus encodes three bona fide ubiquitin-specific proteases. J Virol. 2008; 82:10477-86. | Article | PubMed Abstract | PubMed Full Text

32. Yokoyama N, Fujii K, Hirata M, Tamai K, Kiyono T, Kuzushima K, Nishiyama $Y$, Fujita $M$ and Tsurumi T. Assembly of the epstein-barr virus BBLF4, BSLF1 and BBLF2/3 proteins and their interactive properties. J Gen Virol. 1999; 80 ( Pt 11):2879-87. | Article | PubMed

33. Yoshiyama $\mathrm{H}$, Shimizu $\mathrm{N}$ and Takada K. Persistent Epstein-Barr virus infection in a human T-cell line: unique program of latent virus expression. EMBO J. 1995; 14:3706-11. | PubMed Abstract | PubMed Full Text

34. Whitehurst CB, Ning S, Bentz GL, Dufour F, Gershburg E, Shackelford J, Langelier $Y$ and Pagano JS. The Epstein-Barr virus (EBV) deubiquitinating enzyme BPLF1 reduces EBV ribonucleotide reductase activity. J Virol. 2009; 83:4345-53. | Article | PubMed Abstract | PubMed Full Text

35. Whitehurst CB, Vaziri C, Shackelford J and Pagano JS. Epstein-Barr virus BPLF1 deubiquitinates PCNA and attenuates polymerase eta recruitment to DNA damage sites. J Virol. 2012; 86:8097-106. | Article | PubMed Abstract | PubMed Full Text

36. Saha A, Murakami M, Kumar P, Bajaj B, Sims K and Robertson ES. Epstein-Barr virus nuclear antigen $3 C$ augments $\mathrm{Mdm} 2$-mediated p53 ubiquitination and degradation by deubiquitinating Mdm2. J Virol. 2009; 83:4652-69. | Article | PubMed Abstract | PubMed Full Text

37. Saha A, Halder S, Upadhyay SK, Lu J, Kumar P, Murakami M, Cai Q and Robertson ES. Epstein-Barr virus nuclear antigen 3 C facilitates G1-S transition by stabilizing and enhancing the function of cyclin D1. PLOS Pathog. 2011; 7:e1001275. | Article | PubMed Abstract | PubMed Full Text

38. Inn KS, Lee SH, Rathbun JY, Wong LY, Toth Z, Machida K, Ou JH and Jung JU. Inhibition of RIG-I-mediated signaling by Kaposi's sarcomaassociated herpesvirus-encoded deubiquitinase ORF64. J Virol. 2011; 85:10899-904. | Article | PubMed Abstract | PubMed Full Text

39. Love KR, Catic A, Schlieker C and Ploegh HL. Mechanisms, biology and inhibitors of deubiquitinating enzymes. Nat Chem Biol. 2007; 3:697705. | Article | PubMed 
40. Doherty SD, Barrett TL and Joseph AK. Brooke-Spiegler syndrome: report of a case of multiple cylindromas and trichoepitheliomas. Dermatol Online J. 2008; 14:8. I Article I PubMed

41. Luise C, Capra M, Donzelli M, Mazzarol G, Jodice MG, Nuciforo P, Viale G, Di Fiore PP and Confalonieri S. An atlas of altered expression of deubiquitinating enzymes in human cancer. PLoS One. 2011; 6:e15891. | Article | PubMed Abstract | PubMed Full Text

42. Tao BB, He H, Shi XH, Wang CL, Li WQ, Li B, Dong Y, Hu GH, Hou LJ, Luo C, Chen JX, Chen HR, Yu YH, Sun QF and Lu YC. Up-regulation of USP2a and FASN in gliomas correlates strongly with glioma grade. J Clin Neurosci. 2013; 20:717-20. | Article | PubMed

43. da Silva SD, Cunha IW, Nishimoto IN, Soares FA, Carraro DM, Kowalski LP and Graner E. Clinicopathological significance of ubiquitin-specific protease 2a (USP2a), fatty acid synthase (FASN), and ErbB2 expression in oral squamous cell carcinomas. Oral Oncol. 2009; 45:e134-9. | Article | PubMed

44. Panagopoulos I, Mertens F, Lofvenberg R and Mandahl N. Fusion of the COL1A1 and USP6 genes in a benign bone tumor. Cancer Genet Cytogenet. 2008; 180:70-3. | Article | PubMed

45. Kashuba VI, Gizatullin RZ, Protopopov Al, Allikmets R, Korolev S, Li J, Boldog F, Tory K, Zabarovska V, Marcsek Z, Sumegi J, Klein G, Zabarovsky $E R$ and Kisselev L. Notl linking/jumping clones of human chromosome 3: mapping of the TFRC, RAB7 and HAUSP genes to regions rearranged in leukemia and deleted in solid tumors. FEBS Lett. 1997; 419:181-5. | Article | PubMed

46. Deng S, Zhou H, Xiong R, Lu Y, Yan D, Xing T, Dong L, Tang E and Yang H. Over-expression of genes and proteins of ubiquitin specific peptidases (USPs) and proteasome subunits (PSs) in breast cancer tissue observed by the methods of RFDD-PCR and proteomics. Breast Cancer Res Treat. 2007; 104:21-30. I Article I PubMed

47. Perez-Mancera PA, Rust AG, van der Weyden L, Kristiansen G, Li A, Sarver AL, Silverstein KA, Grutzmann R, Aust D and Rummele $P$ et al. The deubiquitinase USP9X suppresses pancreatic ductal adenocarcinoma. Nature. 2012; 486:266-70. | Article | PubMed Abstract | PubMed Full Text

48. Rolen U, Kobzeva V, Gasparjan N, Ovaa H, Winberg G, Kisseljov F and Masucci MG. Activity profiling of deubiquitinating enzymes in cervical carcinoma biopsies and cell lines. Mol Carcinog. 2006; 45:260-9. Article | PubMed

49. Grunda JM, Nabors LB, Palmer CA, Chhieng DC, Steg A, Mikkelsen T, Diasio RB, Zhang K, Allison D, Grizzle WE, Wang W, Gillespie GY and Johnson MR. Increased expression of thymidylate synthetase (TS), ubiquitin specific protease 10 (USP10) and survivin is associated with poor survival in glioblastoma multiforme (GBM). J Neurooncol. 2006; 80:261-74. | Article | PubMed

50. Chuensumran U, Saelee P, Punyarit P, Wongkham S, Pairojkul C, Chauin $S$ and Petmitr $S$. Ubiquitin-specific protease 14 expression associated with intrahepatic cholangiocarcinoma cell differentiation. Asian Pac J Cancer Prev. 2011; 12:775-9. | Article | PubMed

51. Wang H, Li YP, Chen JH, Yuan SF, Wang L, Zhang JL, Yao Q, Li NL, Bian JF, Fan J, Yi J and Ling R. Prognostic significance of USP22 as an oncogene in papillary thyroid carcinoma. Tumour Biol. 2013; 34:1635-9. | Article | PubMed

52. Ning J, Zhang J, Liu W, Lang $Y, X u e ~ Y$ and Xu S. Overexpression of ubiquitin-specific protease 22 predicts poor survival in patients with early-stage non-small cell lung cancer. Eur J Histochem. 2012; 56:e46. | Article | PubMed Abstract | PubMed Full Text

53. Piao S, Liu Y, Hu J, Guo F, Ma J, Sun Y and Zhang B. USP22 is useful as a novel molecular marker for predicting disease progression and patient prognosis of oral squamous cell carcinoma. PLoS One. 2012; 7:e42540. | Article | PubMed Abstract | PubMed Full Text

54. Li J, Wang Z and Li Y. USP22 nuclear expression is significantly associated with progression and unfavorable clinical outcome in human esophageal squamous cell carcinoma. J Cancer Res Clin Oncol. 2012; 138:1291-7. | Article | PubMed

55. Yang DD, Cui BB, Sun LY, Zheng HQ, Huang $Q$, Tong JX and Zhang QF. The co-expression of USP22 and BMI-1 may promote cancer progression and predict therapy failure in gastric carcinoma. Cell Biochem Biophys. 2011; 61:703-10. I Article | PubMed

56. Zhang $Y$, Yao L, Zhang X, Ji H, Wang L, Sun S and Pang D. Elevated expression of USP22 in correlation with poor prognosis in patients with invasive breast cancer. J Cancer Res Clin Oncol. 2011; 137:124553. | Article | PubMed

57. Akhavantabasi S, Akman HB, Sapmaz A, Keller J, Petty EM and Erson $A E$. USP32 is an active, membrane-bound ubiquitin protease overexpressed in breast cancers. Mamm Genome. 2010; 21:388-97. Article | PubMed

58. De Pitta C, Tombolan L, Campo Dell'Orto M, Accordi B, te Kronnie G, Romualdi C, Vitulo N, Basso G and Lanfranchi G. A leukemiaenriched cDNA microarray platform identifies new transcripts with relevance to the biology of pediatric acute lymphoblastic leukemia. Haematologica. 2005; 90:890-8. | Article | PubMed

59. Paulsson K, Bekassy AN, Olofsson T, Mitelman F, Johansson B and Panagopoulos I. A novel and cytogenetically cryptic t(7;21)(p22;q22) in acute myeloid leukemia results in fusion of RUNX1 with the ubiquitinspecific protease gene USP42. Leukemia. 2006; 20:224-9. | Article | PubMed

60. Zhang Y, van Deursen J and Galardy PJ. Overexpression of ubiquitin specific protease 44 (USP44) induces chromosomal instability and is frequently observed in human T-cell leukemia. PLoS One. 2011; 6:e23389. | Article | PubMed Abstract | PubMed Full Text

61. Perez-Magan E, Campos-Martin Y, Mur P, Fiano C, Ribalta T, Garcia JF, Rey JA, Rodriguez de Lope A, Mollejo M and Melendez B. Genetic alterations associated with progression and recurrence in meningiomas. J Neuropathol Exp Neurol. 2012; 71:882-93. | Article | PubMed

62. Xiang T, Li L, Yin X, Yuan C, Tan C, Su X, Xiong L, Putti TC, Oberst M, Kelly $\mathrm{K}$, Ren $\mathrm{G}$ and Tao $\mathrm{Q}$. The ubiquitin peptidase UCHL1 induces $\mathrm{GO} / \mathrm{G} 1$ cell cycle arrest and apoptosis through stabilizing p53 and is frequently silenced in breast cancer. PLoS One. 2012; 7:e29783. | Article | PubMed Abstract | PubMed Full Text

63. Chen Y, Fu D, Xi J, Ji Z, Liu T, Ma Y, Zhao Y, Dong L, Wang Q and Shen X Expression and clinical significance of UCH37 in human esophagea squamous cell carcinoma. Dig Dis Sci. 2012; 57:2310-7. | Article | PubMed

64. Read J. Recent advances in cutaneous melanoma: towards a molecular model and targeted treatment. Australas J Dermatol. 2013; 54:163-72. | Article | PubMed

65. Draker R, Sarcinella E and Cheung P. USP10 deubiquitylates the histone variant H2A.Z and both are required for androgen receptor-mediated gene activation. Nucleic Acids Res. 2011; 39:3529-42. | Article | PubMed Abstract | PubMed Full Text

66. Khoronenkova SV and Dianov GL. USP7S-dependent inactivation of Mule regulates DNA damage signalling and repair. Nucleic Acids Res. 2013; 41:1750-6. | Article | PubMed Abstract | PubMed Full Text

67. Zhang L, Lubin A, Chen H, Sun Z and Gong F. The deubiquitinating protein USP24 interacts with DDB2 and regulates DDB2 stability. Cell Cycle. 2012; 11:4378-84. | Article | PubMed Abstract | PubMed Full Text

68. Morris JR. Attenuation of the ubiquitin conjugate DNA damage signal by the proteasomal DUB POH1. Cell Cycle. 2012; 11:4103-4. | Article | PubMed Abstract | PubMed Full Text

69. Metzig M, Nickles D, Falschlehner C, Lehmann-Koch J, Straub BK, Roth W and Boutros M. An RNAi screen identifies USP2 as a factor required for TNF-alpha-induced NF-kappaB signaling. Int J Cancer. 2011; 129:607-18. | Article | PubMed 
70. Fan YH, Yu Y, Mao RF, Tan XJ, Xu GF, Zhang H, Lu XB, Fu SB and Yang J. USP4 targets TAK1 to downregulate TNFalpha-induced NF-kappaB activation. Cell Death Differ. 2011; 18:1547-60. | Article | PubMed Abstract | PubMed Full Text

71. Sun W, Tan X, Shi Y, Xu G, Mao R, Gu X, Fan Y, Yu Y, Burlingame S, Zhang H, Rednam SP, Lu X, Zhang T, Fu S, Cao G, Qin J and Yang J. USP11 negatively regulates TNFalpha-induced NF-kappaB activation by targeting on IkappaBalpha. Cell Signal. 2010; 22:386-94. | Article | PubMed Abstract | PubMed Full Text

72. Chen $R$, Zhang L, Zhong B, Tan B, Liu $Y$ and Shu HB. The ubiquitinspecific protease 17 is involved in virus-triggered type I IFN signaling. Cell Res. 2010; 20:802-11. | Article | PubMed

73. Santin I, Moore F, Grieco FA, Marchetti P, Brancolini C and Eizirik DL. USP18 is a key regulator of the interferon-driven gene network modulating pancreatic beta cell inflammation and apoptosis. Cell Death Dis. 2012; 3:e419. | Article | PubMed Abstract | PubMed Full $\underline{\text { Text }}$

74. Zhong B, Liu X, Wang X, Chang SH, Wang A, Reynolds JM and Dong C. Negative regulation of IL-17-mediated signaling and inflammation by the ubiquitin-specific protease USP25. Nat Immunol. 2012; 13:1110-7. | Article | PubMed Abstract | PubMed Full Text

75. da Silva CG, Studer P, Skroch M, Mahiou J, Minussi DC, Peterson CR, Wilson SW, Patel VI, Ma A, Csizmadia E and Ferran C. A20 promotes liver regeneration by decreasing SOCS3 expression to enhance IL-6/ STAT3 proliferative signals. Hepatology. 2013; 57:2014-25. | Article | PubMed

76. Won M, Park KA, Byun HS, Sohn KC, Kim YR, Jeon J, Hong JH, Park J, Seok JH, Kim JM, Yoon WH, Jang IS, Shen HM, Liu ZG and Hur GM. Novel anti-apoptotic mechanism of A20 through targeting ASK1 to suppress TNF-induced JNK activation. Cell Death Differ. 2010; 17:183041. | Article | PubMed

77. Blazusiak E, Florczyk D, Jura J, Potempa J and Koziel J. Differential regulation by Toll-like receptor agonists reveals that MCPIP1 is the potent regulator of innate immunity in bacterial and viral infections. $J$ Innate Immun. 2013; 5:15-23. | Article | PubMed

78. Pringle LM, Young R, Quick L, Riquelme DN, Oliveira AM, May MJ and Chou MM. Atypical mechanism of NF-kappaB activation by TRE17/ ubiquitin-specific protease 6 (USP6) oncogene and its requirement in tumorigenesis. Oncogene. 2012; 31:3525-35. | Article | PubMed Abstract | PubMed Full Text

79. Colleran A, Collins PE, O'Carroll C, Ahmed A, Mao X, McManus B, Kiely PA, Burstein E and Carmody RJ. Deubiquitination of NF-kappaB by Ubiquitin-Specific Protease-7 promotes transcription. Proc Natl Acad Sci U S A. 2013; 110:618-23. | Article | PubMed Abstract | PubMed Full Text

80. Shembade $\mathrm{N}$ and Harhaj EW. Regulation of NF-kappaB signaling by the A20 deubiquitinase. Cell Mol Immunol. 2012; 9:123-30. | Article | $\underline{\text { PubMed Abstract } \mid \text { PubMed Full Text }}$

81. Hu H, Brittain GC, Chang JH, Puebla-Osorio N, Jin J, Zal A, Xiao Y, Cheng $X$, Chang M, Fu YX, Zal T, Zhu C and Sun SC. OTUD7B controls noncanonical NF-kappaB activation through deubiquitination of TRAF3. Nature. 2013; 494:371-4. | Article I PubMed Abstract | PubMed Full $\underline{\text { Text }}$

82. Liang J, Saad Y, Lei T, Wang J, Qi D, Yang Q, Kolattukudy PE and Fu M. MCP-induced protein 1 deubiquitinates TRAF proteins and negatively regulates JNK and NF-kappaB signaling. J Exp Med. 2010; 207:2959-73. | Article | PubMed Abstract | PubMed Full Text

83. Yamaguchi T, Kimura J, Miki Y and Yoshida K. The deubiquitinating enzyme USP11 controls an IkappaB kinase alpha (IKKalpha)-p53 signaling pathway in response to tumor necrosis factor alpha (TNFalpha). J Biol Chem. 2007; 282:33943-8. | Article | PubMed

84. Liu YL, Jiang SX, Yang YM, Xu H, Liu JL and Wang XS. USP22 acts as an oncogene by the activation of BMI-1-mediated INK4a/ARF pathway and Akt pathway. Cell Biochem Biophys. 2012; 62:229-35. | Article | PubMed

85. Das CM, Taylor P, Gireud M, Singh A, Lee D, Fuller G, Ji L, Fangusaro J, Rajaram V, Goldman S, Eberhart C and Gopalakrishnan V. The deubiquitylase USP37 links REST to the control of p27 stability and cell proliferation. Oncogene. 2013; 32:1691-701. | Article | PubMed Abstract | PubMed Full Text

86. Sun XX, Challagundla KB and Dai MS. Positive regulation of $p 53$ stability and activity by the deubiquitinating enzyme Otubain 1. EMBO J. 2012; 31:576-92. | Article | PubMed Abstract | PubMed Full $\underline{\text { Text }}$

87. Zhiqiang Z, Qinghui Y, Yongqiang Z, Jian Z, Xin Z, Haiying $M$ and Yuepeng G. USP1 regulates AKT phosphorylation by modulating the stability of PHLPP1 in lung cancer cells. J Cancer Res Clin Oncol. 2012; 138:1231-8. | Article | PubMedt

88. Panner A, Crane CA, Weng C, Feletti A, Fang S, Parsa AT and Pieper RO. Ubiquitin-specific protease 8 links the PTEN-Akt-AIP4 pathway to the control of FLIPS stability and TRAIL sensitivity in glioblastoma multiforme. Cancer Res. 2010; 70:5046-53. | Article | PubMed Abstract I PubMed Full Text

89. Agrawal P, Chen YT, Schilling B, Gibson BW and Hughes RE. Ubiquitin-specific peptidase 9 , X-linked (USP9X) modulates activity of mammalian target of rapamycin (mTOR). J Biol Chem. 2012; 287:21164-75. | Article | PubMed Abstract | PubMed Full Text

90. Hussain S, Feldman AL, Das C, Ziesmer SC, Ansell SM and Galardy PJ. Ubiquitin hydrolase UCH-L1 destabilizes mTOR complex 1 by antagonizing DDB1-CUL4-mediated ubiquitination of raptor. Mol Cell Biol. 2013; 33:1188-97. | Article | PubMed Abstract | PubMed Full Text

91. De Boeck $M$ and ten Dijke P. Key role for ubiquitin protein modification in TGFbeta signal transduction. Ups J Med Sci. 2012; 117:153-65. | Article | PubMed Abstract | PubMed Full Text

92. Zhong J, Zhao M, Ma Y, Luo Q, Liu J, Wang J, Yuan X, Sang J and Huang C. UCHL1 acts as a colorectal cancer oncogene via activation of the beta-catenin/TCF pathway through its deubiquitinating activity. Int J Mol Med. 2012; 30:430-6. | Article | PubMed

93. Cotto-Rios XM, Bekes M, Chapman J, Ueberheide B and Huang TT. Deubiquitinases as a signaling target of oxidative stress. Cell Rep. 2012; 2:1475-84. | Article | PubMed Abstract | PubMed Full Text

94. Kim H, Lee JM, Lee G, Bhin J, Oh SK, Kim K, Pyo KE, Lee JS, Yim HY, Kim $\mathrm{KI}$, Hwang $\mathrm{D}$, Chung J and Baek SH. DNA damage-induced RORalpha is crucial for p53 stabilization and increased apoptosis. Mol Cell. 2011; 44:797-810. | Article | PubMed

95. Takahashi M, Higuchi M, Matsuki H, Yoshita M, Ohsawa T, Oie M and Fujii M. Stress granules inhibit apoptosis by reducing reactive oxygen species production. Mol Cell Biol. 2013; 33:815-29. | Article | PubMed Abstract | PubMed Full Text

96. Storz P, Doppler H, Ferran C, Grey ST and Toker A. Functional dichotomy of $A 20$ in apoptotic and necrotic cell death. Biochem J. 2005; 387:47-55. | Article | PubMed Abstract | PubMed Full Text

97. Xu Z, Zheng Y, Zhu Y, Kong X and Hu L. Evidence for OTUD-6B participation in $B$ lymphocytes cell cycle after cytokine stimulation. PLoS One. 2011; 6:e14514. | Article | PubMed Abstract | PubMed Full $\underline{\text { Text }}$

98. Li Z, Wang D, Messing EM and Wu G. VHL protein-interacting deubiquitinating enzyme $\mathbf{2}$ deubiquitinates and stabilizes HIF-1alpha. EMBO Rep. 2005; 6:373-8. | Article | PubMed Abstract | PubMed Full $\underline{\text { Text }}$

99. Liu Z, Zanata SM, Kim J, Peterson MA, Di Vizio D, Chirieac LR, Pyne S, Agostini M, Freeman MR and Loda M. The ubiquitin-specific protease USP2a prevents endocytosis-mediated EGFR degradation. Oncogene. 2013; 32:1660-9. | Article | PubMed 
100. Berlin I, Schwartz H and Nash PD. Regulation of epidermal growth factor receptor ubiquitination and trafficking by the USP8.STAM complex. J Biol Chem. 2010; 285:34909-21. | Article | PubMed Abstract I PubMed Full Text

101. Duex JE and Sorkin A. RNA interference screen identifies Usp18 as a regulator of epidermal growth factor receptor synthesis. Mol Biol Cell. 2009; 20:1833-44. | Article | PubMed Abstract | PubMed Full Text

102. Altun M, Zhao B, Velasco K, Liu H, Hassink G, Paschke J, Pereira T and Lindsten K. Ubiquitin-specific protease 19 (USP19) regulates hypoxiainducible factor 1alpha (HIF-1alpha) during hypoxia. J Biol Chem. 2012; 287:1962-9. | Article | PubMed Abstract | PubMed Full Text

103. Buus R, Faronato M, Hammond DE, Urbe $S$ and Clague MJ. Deubiquitinase activities required for hepatocyte growth factorinduced scattering of epithelial cells. Curr Biol. 2009; 19:1463-6. Article I PubMed Abstract I PubMed Full Text

104. Flugel D, Gorlach A and Kietzmann T. GSK-3beta regulates cell growth, migration, and angiogenesis via Fbw7 and USP28-dependent degradation of HIF-1alpha. Blood. 2012; 119:1292-301. | Article | PubMed Abstract | PubMed Full Text

105. Pareja F, Ferraro DA, Rubin C, Cohen-Dvashi H, Zhang F, Aulmann S, Ben-Chetrit N, Pines G, Navon R, Crosetto N, Kostler W, Carvalho S, Lavi S, Schmitt F, Dikic I, Yakhini Z, Sinn P, Mills GB and Yarden Y. Deubiquitination of EGFR by Cezanne-1 contributes to cancer progression. Oncogene. 2012; 31:4599-608. | Article | PubMed Abstract I PubMed Full Text

106. Qi Y, Liang J, She ZG, Cai Y, Wang J, Lei T, Stallcup WB and Fu M. MCPinduced protein 1 suppresses TNFalpha-induced VCAM-1 expression in human endothelial cells. FEBS Lett. 2010; 584:3065-72. | Article | PubMed Abstract | PubMed Full Text

107. Mei Y, Hahn AA, Hu S and Yang X. The USP19 deubiquitinase regulates the stability of c-IAP1 and c-IAP2. J Biol Chem. 2011; 286:35380-7. Article I PubMed Abstract | PubMed Full Text

108. Qi D, Huang S, Miao R, She ZG, Quinn T, Chang Y, Liu J, Fan D, Chen YE and Fu M. Monocyte chemotactic protein-induced protein 1 (MCPIP1) suppresses stress granule formation and determines apoptosis under stress. J Biol Chem. 2011; 286:41692-700. | Article | PubMed Abstract | PubMed Full Text

\section{Citation:}

Saxena N and Kumar V. Oncogenic viruses: DUBbing their way to cancer. Virol Discov. 2013; 1:5. http://dx.doi.org/10.7243/2052-6202-1-5 